Rising Seas and Common Law Baselines: A Comment on Regulatory Takings Discourse Concerning Climate Change

J. Peter Byrne

Georgetown University Law Center, byrne@law.georgetown.edu

This paper can be downloaded free of charge from:

https://scholarship.law.georgetown.edu/facpub/338

11 Vt. J. Envtl. L. 627-642 (2010)

This open-access article is brought to you by the Georgetown Law Library. Posted with permission of the author. Follow this and additional works at: https://scholarship.law.georgetown.edu/facpub

Part of the Administrative Law Commons, Constitutional Law Commons, and the Environmental Law Commons 


\section{GEORGETOWN LAW Faculty Publications}

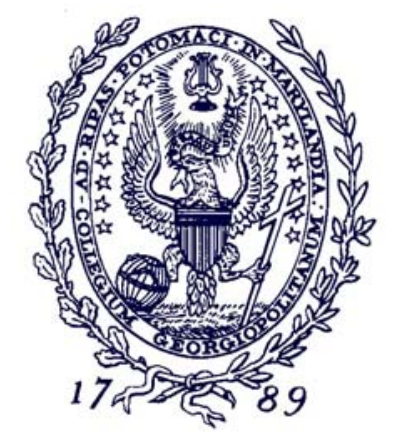

Georgetown Public Law and Legal Theory Research Paper No. 10-23 April 2010

\section{Rising Seas and Common Law Baselines: A Comment on Regulatory Takings Discourse Concerning Climate Change}

11 Vt. J. Envtl. L. 627-642 (2010)

\section{J. Peter Byrne}

Professor of Law

Georgetown University Law Center

byrne@law.georgetown.edu

This paper can be downloaded without charge from:

Scholarly Commons: http://scholarship.law.georgetown.edu/facpub/338/

SSRN: http://ssrn.com/abstract $=1593595$

Posted with permission of the author 


\title{
Rising SEAS AND CoMmon LAw BASELines: A COMMENT ON REGULATORY TAKINGS DISCOURSE Concerning Climate Change
}

\begin{abstract}
J. Peter Byrne*
This essay examines adaptation of property law to rapid changes in resource character through climate change. My jurisprudential concern is with judicial disfavoring of legislative adjustments of common law entitlements. My doctrinal concern focuses on regulatory takings challenges to legislative programs to adapt to rising sea levels. Legal adaptation to fast and large changes in resources, such as through sea level rise, will require inventive legislation. It already has become a cliché that climate change changes everything. But some courts privilege common law rights over legislative realignment, invoking the Takings Clause or other constitutional provisions. This essay will examine this problem in the context of current cases wrestling with legislation that purports to govern the allocation of rights to beaches between private owners and the public.

Sea levels have been rising at an accelerating rate in recent years. ${ }^{1}$ Substantial sea level rise is nearly certain to occur in subsequent decades as a consequence of global warming regardless of what mitigation measures government or private citizens adopt. $^{2}$ Public and private land will Peter Amaro.

* Professor of Law, Georgetown University Law Center. Thanks for research help goes to

1. Intergovernmental Panel on Climate Change, Climate Change 2007: Synthesis REPORT 30-31 (2007), available at http://www.ipcc.ch/pdf/assessment-report/ar4/syr/ar4_syr.pdf.

2. David A. Farenthold, Rise in Sea Level Threatens Atlantic Coastline, WASH. POST, Oct. 28, 2009, http://www.washingtonpost.com/wp-dyn/content/article/2009/10/27/AR2009102703915.html. The Virginia Governor's Commission on Climate Change, for example, predicted that the Commonwealth will face 2.3 to 5.2 feet of sea level rise, which will result in increased flooding and storm surge in vulnerable coastal areas. GOVERNOR's COMM'N ON CLIMATE CHANGE, FINAL REPORT: A Climate CHANGE ACTION Plan 5-7 (2008), available at http://www.deq.virginia.gov/export/sites/default/info/documents/climate/CCC_Final_Report-

Final_12152008.pdf. A recent paper argues, based upon a study of sea level rises during the last interglacial period, that seas may rise during the current warming trend by twenty to thirty feet on
\end{abstract}


disappear beneath the waves and buildings will be destroyed. More severe storms may well aggravate the loss of land and buildings. The mean high tide line, which typically marks the division between public trust tidelands and privately owned dry land, will move inland. ${ }^{3}$ Under traditional common law rules governing erosion, the migration of the mean high tide line will change ownership of locations from private owners to the public. ${ }^{4}$ The seas will engulf wetlands, which may establish themselves in locations formerly dry and inland. Private owners, of course, have the incentive to resist these outcomes, either through armoring the shore or through legal arguments. Public officials will have complex incentives and duties: protecting environmental resources (such as dunes and wetlands), securing public rights, promoting economic development, and satisfying constituents, including littoral property owners. But the dramatic changes being brought about by climate change will require rapid developments in rules based upon scientific understandings and the balancing of competing interests that legislatures accomplish better than courts.

Because my underlying concern in this essay is jurisprudential, I will not argue here for any particular regulatory approach for adapting to rising sea levels. Instead, I will consider three approaches, all of which reflect recent judicial decisions or legislative proposals. First is public financing of beach restoration accompanied by fixing the formerly mobile line between public and private land. This is the approach at issue in Stop the Beach Renourishment v. Florida Department of Environmental Protection. ${ }^{5}$ Second is the advance inland, or "rolling," of public easements over eroding, formerly unburdened private land. This is the problem addressed in Severance v. Patterson. ${ }^{6}$ The third scenario considers plausible proposals to enact legislation that restricts the ability of private landowners to erect seawalls or other structures meant to protect their land from

average. Robert E. Kopp et al, Probabilistic Assessment of Sea Level During the Last Interglacial Stage, 462 NATURE 863 (2009).

3. James G. Titus, Rising Seas, Coastal Erosion, and the Takings Clause: How to Save Wetlands and Beaches Without Hurting Property Owners, 57 MD. L. REv. 1279, 1365-66 (1998).

4. HENRY PHILIP FARNHAM, The LAW OF WATERS AND WATER RightS 320-23 (The Lawbook Exchange, Ltd. 2006) (1904).

5. Walton County v. Stop the Beach Renourishment, Inc., 998 So. 2d 1102, 1106 (Fla. 2008), cert. granted, 77 U.S.L.W. 3673 (U.S. June 15, 2009) (No. 08-1151) (At the Supreme Court level, the party names are now Stop the Beach Renourishment, Inc. v. Florida Department of Environmental Protection.).

6. Severance v. Patterson, 566 F.3d 490, 493, 503-04 (5th Cir. 2009). 
inundation and the passing to public ownership due to sea level rise. Meg Caldwell proposes something to this effect in a recent article. ${ }^{7}$

Each of these three scenarios raises regulatory takings issues. In decisions addressing these issues, courts have placed weight on whether public restraints on private rights accord with the common law. This strikes me as unjustified. Such judicial attitudes threaten the ability of the appropriate public authorities to respond to sea level rise in an environmentally responsible manner. The question should not be whether the common law once treated seaside rights in a certain way, but whether contemporary legislation is fair to all interested parties.

This paper analyzes the takings implications of different legal adaptations to sea level rise, with particular attention to the normative precedence given to common law rights. The weight given to common law rights over legislative regulation may be endemic to the regulatory takings area because legislation modifies the common law but not vice versa. But judicial privileging of common law baselines took on another dimension in Lucas v. South Carolina Costal Council, where the Court used them as "background principles" that provided a crucial measure of the constitutional authority of legislatures. ${ }^{8}$ Unfairness to owners from reasonably unanticipated changes in the law is a long-standing element in regulatory takings analysis, but more seems to be at issue here. Courts seem to be moved by a more general concern about whether limitations on use can be said to "inhere in the title," or should be viewed merely as political constraints external to the title.

In another paper, I have argued that the character of many common law property rules reflect more the institutional limitations of the common law than a fixed normative judgment about the content of those rules. ${ }^{9}$ The resources of modern legislation and ongoing administrative regulation broaden the capacity of the government to register and reflect a broader array of interests and values than common law courts could manage. Thus, I argued that common law courts refused to recognize security interests in

7. Meg Caldwell \& Craig Holt Segall, No Day at the Beach: Sea Level Rise, Ecosystem Loss, and Public Access Along the California Coast, 34 Ecology L.Q. 533, 566-67 (2007).

8. Lucas v. S.C. Coastal Council, 505 U.S. 1003, 1029 (1992). Lucas is discussed further below.

9. J. Peter Byrne, The Public Nature of Property Rights and the Property Nature of Public Law, in The Public NATURe of Property Rights (Michael Diamond ed., forthcoming 2010) (manuscript at 4 , on file with author). 
personal property or protect a resident's interest in existing natural light, for example, not because these claims were normatively unattractive, but because they could not be protected in common law adjudication without daunting negative consequences. Legislative and administrative innovations effectively solved these problems through establishing a recording system for security interests in personal property and through zoning setbacks and height limitations, both protecting a broader array of interests with reasonable efficiency. My claim was not that legislative adjustments of property rights are always superior to common law rules, but that they are legitimate parts of property law and have capacities to recognize a broader array of interests, manage information to prevent private losses, and adjust private rights to public needs.

Let us turn to the current cases that illustrate the courts' fixation on the common law origins of old law. At bottom, Stop the Beach Renourishment challenges the constitutionality of Florida's Beach and Shore Preservation Act. ${ }^{10}$ Under the Act, the State, at the request and with the assistance of the relevant local government, restores eroded beaches at public expense. ${ }^{11}$ As part of the process, the state fixes a new boundary between the tidal public trust lands and adjacent private littoral lands, based on the historic mean high tide line. ${ }^{12}$ After the boundary is fixed, the property line does not move seaward or landward so long as the state maintains the restored beach. ${ }^{13}$ The purpose of this is obvious. It would be absurd for the state to pay to restore the beach if much of the new land was to become privately owned. This program does confer substantial benefits on private littoral owners. The restored beach protects their adjacent land from erosion and storm damage. The Act also provides specific legal protections to the littoral owners, such as guarantees of their unimpeded views of and access to the sea. ${ }^{14}$ No private land actually is taken, as the beach has to be eroded to qualify for restoration, and the new dry land was previously under water. The private owner litigants claim that the Act deprives them of the property right to obtain future increases from accretion. ${ }^{15}$ So. $2 \mathrm{~d}$ at 1107

10. FLA. StAT. ANN. §§ 161.011-161.76 (2006); Stop the Beach Renourishment, Inc., 998

11. $\S 161.26$.

12. $\S 161.141$.

13. $\S 161.191$

14. § 161.201.

15. Stop the Beach Renourishment, Inc., 998 So. 2d at 1107. 
Stop the Beach Renourishment challenges as a "judicial taking" the Florida Supreme Court's interpretation of its precedent in arriving at the conclusion that the littoral owners never had a distinct right at common law to own future accretions. ${ }^{16}$ While there are numerous problems with a judicial takings theory based on state court interpretation of state common law, ${ }^{17}$ I want to focus on the framing of the case around the Florida common law baseline. The Florida Supreme Court felt that it needed to parse the common law rights of the private owners, and the U.S. Supreme Court granted certiorari to determine whether that parsing violated the federal constitution. ${ }^{18}$ But none of this should matter. The Act plainly changed the way that the boundaries of the littoral lands would be determined and did so to enable a new approach to reversing beach erosion based on modern technology, fairly balancing private and public interests. There is no suggestion here that the littoral owners relied on or were surprised by the change. Indeed, the Act was enacted in 1970, long before the 1987 court decision that is primarily relied on by the owners as precedent. Furthermore, there was no evidence of when the owners actually acquired their lands. ${ }^{19}$ The landowners did not introduce any evidence of loss of value; it seems most likely that the state's actions increased the value of their property by essentially ruling out the likelihood of erosion and providing an adjacent wide sandy beach. ${ }^{20}$

16. Brief of Petitioner at 16-18, Stop the Beach Renourishment, Inc. v. Fla. Dep’t of Envtl. Prot., No. 08-1151 (July 13, 2009). The concept of a judicial taking is that a judicial change in the dimension of a common law property right might be analyzed as a regulatory taking in a manner similar to how courts analyze legislative limitations on property rights. Barton H. Thompson, Jr., Judicial Takings, 76 VA. L. REV. 1449, 1449-50 (1990).

17. Here are two examples. First, courts have frequently changed the common law of property to adapt to new circumstances or understandings, even though such changes have inflicted harm on some owners. See, e.g., Morton J. Horwitz, The Transformation Of AMERICAN LAW, 1780-1860 at 31, 37 (1977) (discussing the transformation in the conception of property); Louise A. Halper, Nuisance, Courts and Markets in the New York Court of Appeals, 1850-1915, 54 ALB. L. REv. 301, 302 03 (1990); Joseph L. Sax, Property Rights and the Economy of Nature: Understanding Lucas v. South Carolina Costal Council, 45 STAN. L. REv. 1433, 1447-48 (1993). The U.S. Constitution never has been, nor should it be, construed to give federal courts the authority to oversee or prevent this necessary legal adaptation. Sauer v. New York, 206 U.S. 536, 546 (1907) (rejecting judicial takings argument). Second, the U.S. Supreme Court already has the doctrinal means to prevent state courts from frustrating federal rights through state law rulings that lack a "fair and substantial basis." Staub v. City of Baxley, 355 U.S. 313, 318-19 (1958).

18. Stop the Beach Renourishment, Inc., 998 So. 2d at 1102.

19. See id. (making no mention of when the land was acquired).

20. Id. at 1115 . 
The petitioners' arguments in Stop the Beach Renourishment do not invoke key elements in regulatory takings doctrine. ${ }^{21}$ The state does not occupy any land that formerly had been private. The owners do not claim that their property has suffered a great economic loss or that the Act surprised them; as such, their reasonable economic expectations have not been frustrated. Nor do they argue that they have been deprived of a common law property interest explicitly bargained for, as in Pennsylvania Coal Co. v. Mahon. ${ }^{22}$ Rather, they complain simply that they had enjoyed a common law right to accretion that has been eliminated by the Act and by the Florida Supreme Court's ruling. ${ }^{23}$ It is a puzzle why such an argument should have any traction today. No one disputes that the common law can be superseded by statute. ${ }^{24}$

Severance v. Patterson presents a scenario just as likely to be relevant to sea level rise as Stop the Beach Renourishment, but adopts an opposite adaptation public policy: allowing natural forces to dictate the shape of the coastline. ${ }^{25}$ Texas follows the public trust law of the majority of states in holding that public ownership of the foreshore extends to the mean high tide or wet sand line. ${ }^{26}$ Following judicial clarification of this rule, in 1959 the Texas legislature passed the Texas Open Beach Act (OBA), which provides:

[I]f the public has acquired a right of use or easement to or over an area by prescription, dedication, or has retained a right by virtue of continuous right in the public, the public shall have the free and unrestricted right of ingress and egress to the larger area extending from the line of mean

21. Brief of Petitioner at 16-18, Stop the Beach Renourishment v. Fla. Dep't of Envtl. Prot., No. 08-1151 (July 13, 2009).

22. Pa. Coal Co. v. Mahon, 260 U.S. 393, 412 (1922). In this original regulatory takings decision, legislation had deprived the Pennsylvania Coal Company of the very right to support that it had bargained for previously with the owner of the surface of the land.

23. Brief of Petitioner at 16-18, Stop the Beach Renourishment v. Fla. Dep’t of Envtl. Prot., No. 08-1151 (July 13, 2009).

24. "[C]ourts could not entertain a suggestion that legislation contrary to the doctrines of the common law is invalid.” Roscoe Pound, Common Law and Legislation, 21 HaRv. L. REv. 383, 396 (1908). For the hoary maxim that legislation in derogation of common law rights should be strictly construed, see, e.g., Brown v. Barry, 3 U.S. (3 Dall.) 365, 367 (1797) (acknowledging the power of the legislature to change the common law and expressing conservative judicial suspicion of the legislature).

25. Severance v. Patterson, 566 F.3d 490, 493 (5th Cir. 2009).

26. Id. 
low tide to the line of vegetation bordering on the Gulf of Mexico. ${ }^{27}$

The effect of such an approach is to enable courts to find the existence of public easements on the dry sand beaches. ${ }^{28}$ More to the point of this paper, these are "rolling easements" that move landward with the beach due to erosion or sea level rise, enabling state and local officials to bring actions seeking injunctions to force landowners to remove homes and other improvements from private land that has become beach and thus subject to the easement. ${ }^{29}$

Severance also makes a big deal out of the common law origins of OBA. To some extent, the OBA itself directs analytic focus to the common law, as its provisions turn on whether the public has enjoyed an easement on the state's privately-owned beaches "by prescription, dedication, or has retained a right by virtue of continuous right in the public."30 But Judge Jones treated as relevant whether the rolling nature of any easement existed at common law or was created by the OBA, both to any takings analysis and to her peculiar search and seizure approach. For example, Judge Jones ruled that the owner's takings claim was not ripe because presenting her claim in state court would not be futile, since it is unclear whether Texas courts would deny compensation to the landowner, as they have not issued a definitive ruling on whether the rolling nature of the easement comes from the common law or from the Act, "a critical component of takings analysis.” 31

It is important to note that the Texas scheme builds upon and expands the effect of the public trust doctrine. Normal erosion or sea level rise will move the ownership boundary landward, and private land will become public when tide waters normally lap over it. But the Texas beach easements roll landward in advance of complete public ownership and before water destroys houses and renders private land uninhabitable. For this reason, Texas law interests environmentalists looking for means to

27. TEX. NAt. REs. CodE ANN. § 61.011(a) (Vernon 2001).

28. Very recently, Texas adopted through referendum an amendment enshrining the public right of access to the dry sand beach in the state constitution. TEX. CONST. art. I, § 33(b).

29. See Feinman v. State, 717 S.W.2d 106, 107 (Tex. App. 1986) (demonstrating state and local enforcement of rolling easements).

30. Tex. NAT. Res. Code ANn. § 61.012 (Vernon 2001).

31. Severance v. Patterson, 566 F.3d 490, 499 (5th Cir. 2009). 
manage retreat before rising seawaters. ${ }^{32}$ And for this reason, Texas law has generated many regulatory takings challenges, all of which have been rejected by Texas appellate courts. ${ }^{33}$

Before turning to the third approach to sea level rise, it will be helpful to consider the motives for the solicitude for common law rules reflected in the above two cases. Most everyone acknowledges that "[g]overnment hardly could go on if to some extent values incident to property could not be diminished without paying for every such change in the general law.” ${ }^{\text {"4 }}$ There is something about how the common law shapes property rights that appeals to judges as a moral baseline. I can think of three possible explanations.

First, conservative theorists sometimes privilege judicial over legislative law-making on the ground that legislators respond to the selfinterested lobbying of special interests while judges have sufficient insulation to shape law based on principles such as efficiency or citizen autonomy. The theoretical and empirical problems with this view are substantial, although sorting them out seems inappropriate for a brief paper such as this. ${ }^{35}$ It may be enough to say for the moment that its premise is undercut by the very theory of judicial takings upon which the Court granted certiorari in Stop the Beach Renourishment: courts (except this U.S. Supreme Court) cannot be trusted to preserve property rights! Whatever the weaknesses of our democratic legislative process, it has important capacities superior to judicial lawmaking, such as "comprehensiveness, prospectivity, flexibility, capacity to create and fund institutions, democratic participation in rule formation, and the inclusion of more diffuse interests.” ${ }^{36}$ These virtues are important for aligning property rights with environmental and other communal interests. "[T] here are a number of features of legislative decisionmaking that make it relatively more attractive

32. See, e.g., Caldwell and Segall, supra note 7, at 568 (discussing Texas law).

33. See, e.g., Arrington v. Mattox, 767 S.W.2d 957, 957-58 (Tex. App. 1989) (affirming summary judgment for the state in a regulatory takings case).

34. Pa. Coal Co. v. Mahon, 260 U.S. 393, 413 (1922).

35. See Neil K. Komesar, Imperfect Alternatives: Choosing InStitutions in LAW, ECONOMICS, AND PUBLIC POLICY 149-50 (1994) (discussing judicial independence).

36. Byrne, supra note 9 (manuscript at 18-19). Many of these observations date at least to the early twentieth century Progressives. See, e.g., Int'l News Serv. v. Associated Press, 248 U.S. 215, 264 67 (1918) (Brandeis, J., dissenting) (arguing for the superiority of legislation to judicial rulemaking in adapting intellectual property to new technologies); Pound, supra note 24, at 403-06 (discussing the benefits of legislation). 
than common-law decisionmaking as a basis for modifying or creating categories of property rights." ${ }^{37}$

Second, common property law rules sometimes are thought to embody natural law principles. The U.S. Supreme Court itself has described the littoral owner's right to accretion as vouchsafed by natural law:

The riparian right to future alluvion is a vested right. It is an inherent and essential attribute of the original property. The title to the increment rests in the law of nature. It is the same with that of the owner of a tree to its fruits, and of the owner of flocks and herds to their natural increase. The right is a natural, not a civil one. The maxim "qui sentit onus debet sentire commodum" [he who enjoys the benefit ought also to bear the burdens] lies at its foundation. The owner takes the chances of injury and of benefit arising from the situation of the property. If there be a gradual loss, he must bear it; if a gradual gain, it is his. ${ }^{38}$

One can understand the intuitive justice, all other things being equal, of allowing party $A$ to obtain the benefit of random shifts in property boundaries if party $A$ must tolerate losses from the same risk. But these statutory adaptations to sea level rise address concerns far beyond a simple bilateral game. The doctrine of accretion may have some weak normative appeal as a useful default, but only when no other ethical values or policy goals compete with it. As Professor Sax's historical scholarship shows, the early English cases fashioning the rule for littoral owners assumed that littoral owners would improve new alluvial land for grazing while the crown, the owner of the tidelands, would suffer no harm from the land passing into private ownership. ${ }^{39}$ In other words, it was seen as likely to make the littoral owner better off without injuring anyone else.

Present littoral boundary issues arise in a vastly different natural and legal context. Sea level rise will move boundaries in one directionlandward-with minor variations. This suspends the moral calculation

37. Thomas W. Merrill, Optimal Standardization in the Law of Property: The Numerus Clausus Principle, 110 YALE L.J. 1, 61 (2000).

38. County of St. Clair v. Lovingston, 90 U.S. (23 Wall.) 46, 68-69 (1874); see Nebraska v. Iowa, 143 U.S. 359, 360-61 (1892) (discussing the right to accretion).

39. Jospeh L. Sax, The Accretion/Avulsion Puzzle: Its Past Revealed, Its Future Proposed, TUL. ENVTL. L.J. (forthcoming 2010). 
upon which the appeal of an accretion rule stands. More importantly, climate change and consequent sea level rise pose alarming challenges to environmental resources and public health and safety. ${ }^{40}$ The state has important, if sometimes conflicting, interests in protecting wetlands, sand dunes, habitat, storm buffers, and economic infrastructure. Modern real estate development, despite its many benefits, has both contributed to climate change and made adjusting to it far more difficult. At the same time, the state also has vastly greater scientific understanding, technological capacity, and organizational resources to address sea level rise than it did in the pre-modern era. Modern legislation, appropriations, and administrative oversight provide far more powerful regulatory resources than common law adjudication. While any statutory proposals should be scrutinized for fairness, any natural law arguments that turn on the common law origin of prior law should be dismissed.

Third, libertarian lawyers embrace common law property rules precisely because older cases allow an owner more discretion. Such lawyers distrust all efforts of the democratic state that diminish to any extent values incident to property and thus argue that all reductions in property rights must be compensated. ${ }^{41}$ Common law rules typically predate the administrative state, look primarily to the interests of litigants, and presume that judicial decisions through adjudication will be the principal means of law making. They assume that legislative activity rarely will address underlying resource allocations. Moreover, older decisions are blissfully ignorant of the types of environmental harms that the rational pursuit of self-interest can generate. Thus, treating common law property rules as normative can delegitimize legislative innovations without coming to grips with their goals or substance.

The Lucas decision remains the locus classicus of this method, where the Court equates background principles of property with common law nuisance rules. ${ }^{42}$ But nuisance litigation notoriously fails to adequately weigh the broad public interests present in environmental disputes. ${ }^{43}$

40. Nat’l Acad. of Sciences, Ecological impacts of Climate Change 2 (2009), available at http:/dels.nas.edu/dels/rpt_briefs/ecological_impacts.pdf.

41. See generally Richard A. Epstein, Supreme Neglect: How To Revive COnstitutional Protection For Private Property 163-64 (2008) (arguing for the protection of private property).

42. Lucas v. S.C. Coastal Council, 505 U.S. 1003, 1029 (1992).

43. J. Peter Byrne, Ten Arguments for the Abolition of the Regulatory Takings Doctrine, 22 ECOLOGY L. Q. 89, 114-15 (1995). 
Within the Lucas framework, shoreline protection legislation could be upheld if it replicated common law principles, but not on the basis that they implement reasonable and necessary protections for the environment and public safety. Indeed, the appeal of enshrining the common law baseline seems to be that it avoids frank discussion of the public interests involved in environmental protection and the weight properly afforded to private interests of various sorts. Property rights advocates fear environmental legislation because the proliferation of externalities and the threats to long term welfare threaten to justify dramatic incursion on private dominion over resources. Invoking the common law is a way of obfuscating this reality and talking about something else.

Another case that demonstrates judicial invocation of the common law to derail legislation without discussion of its fairness or efficiency is Phillips v. Washington Legal Foundation. ${ }^{44}$ The case considered a claim that IOLTA accounts, or trust funds in which lawyers are required to pool client funds too small to earn interest individually into accounts that earn cumulative interest and used to support indigent legal services, violate the Takings Clause. ${ }^{45}$ Phillips, rather bizarrely, addressed only whether the interest earned on such IOLTA accounts belongs to the client whose funds the lawyer deposits, even though those funds by definition were too meager to earn interest. Even though positive state and federal law treated the interest earned under IOLTA accounts as owned by the entity that administered indigent legal representation, the Court resorted to the general common law rule that interest follows principal to hold that the owner of the principal in the IOLTA fund owns the interest. ${ }^{46}$ Fortunately for the administration of justice, the Court subsequently held that the compensation due the owner of the principal was zero. ${ }^{47}$ The latter decision highlights the ideal character of the first holding because it illustrates that the right found had been purely notional. Both decisions were five to four. ${ }^{48}$

It is striking that Phillips, like the shoreline cases, involves the principle of accession, i.e. that the new, small element is presumed to be part of the larger contiguous ownership. One might think that the Rehnquist Court might be attaching natural law status to the broader principle of accession.

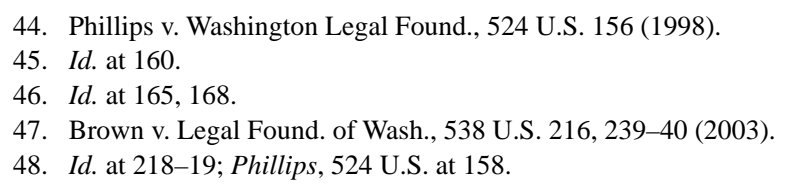


But the greatest modern enthusiast for the principle of accession, Professor Tom Merrill, makes only a very qualified claim for it. He finds it to promote efficiency (at least to a greater extent than the "first possession" principle) because it recognizes the prowess of the owner of the dominant asset by assigning him the gain. ${ }^{49}$ But this rationale has no purchase in the cases of shoreline accretions or IOLTA account interest; owners do not cause gains, which occur either by natural forces or through legislative innovation. Merrill also recognizes several normative objections to accession. $^{50}$ Thus, it is hard to see any normative principle in favor of accession as such that could justify a court giving it precedence over direct statutory directives. The Court merely states that the common law rule must apply when in positive law it does not. It changes the subject from the constitutional merits of the common law.

With these considerations in mind, let us turn to the barriers this attachment to common law baselines imposes on a third statutory approach that is prominently discussed by others for adapting to sea rise caused by climate warming: mandating retreat of development in order to permit wetlands and sand dunes to be re-established landward. Any such policy would be applied selectively to rural coastlines where dunes and marshes already exist and would be justified by the ecological essentiality of such natural features for water quality, fisheries, and storm protection. The statute at issue in Lucas broadly can be understood as such a measure; it prohibited construction of a permanent structure seaward of a line plausibly expected to be underwater in a few years. ${ }^{51}$

For present purposes, consider a state statute less immediately and severely restrictive. Commentators have suggested that all the law need do to ensure a policy of retreat is to prohibit "armoring," that is erection of erosion control structures such as levees and jetties. ${ }^{52}$ Such laws predictably will permit rising sea levels to deprive some private owners of their land. The land will be flooded and thus rendered unusable. Government authorization of flooding of private property generally

49. Thomas W. Merrill, Accession and Original Ownership, 1 J. Legal ANALYsis 459, 461, 489 (2009).

50. Id. at $470-74$.

51. Lucas v. S.C. Coastal Council, 505 U.S. 1003, 1007 (1992); S.C. CoDE ANN. § 48-39-280 to 290 (2008).

52. See Caldwell \& Segall, supra note 7, at 570-74 (discussing several such state statutes). 
amounts to a taking. ${ }^{53}$ Moreover, the public trust doctrine transfers ownership of submerging lands to state ownership as rising waters move the boundary line landward, which creates an effect resembling inverse condemnation.

Yet, there are substantial arguments against treating an anti-armoring statute as causing a regulatory taking. Such a statute would prohibit construction that could harm other property owners and the environment generally. Shoreline fortifications force rising water elsewhere, increasing the flooding of areas that are not protected by such defenses. The statute under discussion arguably solves a prisoner's dilemma, taking away some of the pressure to armor that all would feel in the absence of the statute or an improbable agreement among many littoral owners, making coastal area property owners, as a group, better off. ${ }^{54}$ Armoring would also force rising waters onto existing wetlands and prevent reestablishment of wetlands in geologically suitable locations further inland, thus seriously reducing the quantity of wetlands in violation of long-standing cornerstones of environmental policy. These factors should weigh in any analysis. In this regard, one should note that the Lucas per se rule would not apply, as littoral owners' land would continue to be used and valuable for several years after the prohibition and before the waters rise. Owners would not lose all of the present value of their land.

Most importantly, the destruction of the owner's estate will result from sea level rise, not the statute, which only forbids a defensive device to postpone the problem but imposes substantial harms on others. Littoral owners may have nuisance claims against large emitters of greenhouse gases. ${ }^{55}$ Indeed, they might have a more sympathetic claim against the United States for failing to curb emissions than against the government enacting the probation of armoring, although I know of no precedent for a government omission (rather than an act) providing a basis for a takings claim. Similarly, the exchange of ownership from the private owners to the

53. Pumpelly v. Green Bay Co., 80 U.S. (13 Wall.) 166, 181 (1871).

54. See Caldwell \& Segall, supra note 7, at 574-75 (discussing the economic benefits of restrictions on armoring).

55. See, e.g., Connecticut v. Am. Elec. Power Co., Inc., 582 F.3d 309, 310 (2d Cir. 2009) (reinstating case based on the public nuisance of global warming). The argument in this paper does not imply that existing statutes or regulations displace common law rights, such as those involved in American Electric Power, but that the constitutional validity of any future statutes that do displace the common law should be assessed without regard to the fact that the rights private owners had before enactment were common law rather than statutory rights. 
government under the public trust doctrine would be the result of natural forces, not legal will. Moreover, the private owners' erection of defenses can be seen to invade the rights of the sovereign to gain by sea level rise. As the court recently held in United States v. Milner, "because both the upland and tideland owners [the Lummi Indian tribe] have a vested right to gains from the ambulation of the boundary, the Homeowners cannot permanently fix the property boundary, thereby depriving the Lummi of tidelands that they would otherwise gain." 56

One issue that property owners likely will raise is that such a statute deprives littoral owners of their common law right to wall out the sea. At common law, a landowner could erect a sea wall to protect against erosion and was not liable for the diversion of the waters onto the land of his neighbors, a variant of the common enemy rule for casual surface water. ${ }^{57}$ Reflecting the view embedded within Stop the Beach Renourishment and Severance, upland owners could claim that the right to armor the coastline is inherent in littoral title, so that a statute prohibiting it deprives them of their property right. ${ }^{58}$ Indeed, in two significant modern cases involving construction of sea walls, state supreme courts have had to resort to creative interpretations of state common law to reject landowners' claims that they had a common law right to wall out seawater. ${ }^{59}$ In Shell Island Homeowners Association v. Tomlinson, the North Carolina Court of Appeals rejected the property owners' constitutional challenge to a state statute

56. United States v. Milner, 583 F.3d 1174, 1187 (9th Cir. 2009).

57. See, e.g., Cass v. Dicks, 44 P. 113, 114 (Wash. 1896) (providing an example of the common law application to sea wall construction). In Cass, the court quoted with approval from a treatise: If a landowner whose lands are exposed to inroads of the sea, or to inundations from adjacent creeks or rivers, erects sea walls or dams for the protection of his land, and by so doing causes the tide, the current, or the waves to flow against the land of his neighbor, and wash it away, or cover it with water, the landowner so causing an injury to his neighbor is not responsible in damages to the latter, as he has done no wrong, having acted in self-defense, and having a right to protect his land and his crops from inundation.

Id. (citing EDWARD P. WEEKS, DAMNUM ABSQUE INJURIA 3-4 (1879)).

58. "[I]f the State refuses to allow construction of some protective device, the oceanfront property owners, whose houses or other structures face destruction from the relentless forces of nature, believe that they are being denied the exercise of some fundamental common law littoral right to protect their property.” Joseph J. Kalo, North Carolina Oceanfront Property and Public Waters and Beaches: The Rights of Littoral Owners in the Twenty-First Century, 83 N.C. L. REv. 1427, 1431-32 (2005).

59. Shell Island Homeowners Ass'n v. Tomlinson, 517 S.E.2d 406 (N.E. Ct. App. 1999); Grundy v. Thurston County, 117 P.3d 1089, 1090 (Wash. 2005). 
prohibiting construction of seawalls. ${ }^{60}$ The property owners based their takings claim on the argument that "the protection of property from erosion is an essential right of property owners." ${ }^{61}$ The court summarily rejected the argument as having "no support in the law," although Professor Kalo, while highly sympathetic to the policy of the statute, commented that "the issue of whether waterfront property owners have any common law right to erect hardened structures in statutorily designated areas of environmental concern is not as simple as the court makes it appear."62

In the other case, Grundy v. Thurston County, the Washington Supreme Court held that the common enemy rule did not apply to seawater, despite language in prior decisions strongly suggesting that it did. ${ }^{63}$ Thus, these courts had to sift moldy common law precedents to find some accordance with contemporary statutory approaches, much in the same way as the court did in Stop the Beach Renourishment. Similar to that case, the buildings at issue in Shell Island were permitted after the regulations challenged were adopted, so that unfair surprise was not at issue. The displacement of common law was advanced as an independent ground for the invalidity of the challenged statutory approach, so that courts felt that they had to interpret the common law not to include the rule.

The purpose of this essay is to argue that courts should not need to worry about the old common law rule, adopted under vastly different assumptions. No constitutional or jurisprudential principle gives it precedence over the subsequent statute. There may be circumstances where a ban on armoring might constitute a regulatory taking, for example, where the prior law had led an owner to rely on a legal right to armor that was taken away suddenly resulting in a wipeout. In such circumstances, it should not matter whether the baseline rule was common law or statutory, nor whether the change was a new statute or a clear change in the common law. Moreover, even if not a constitutional violation, a new statutory prohibition may authorize some compensation for reasons of either fairness or politics. There may be unfairness to littoral owners from the application of a common law rule shifting boundaries with the mean high tide line when sea level rise creates a one-way shift. The one point argued here is

60. Tomlinson, 517 S.E.2d at 414 .

61. Id.

62. Kalo, supra note 58, at 1489.

63. Grundy, 117 P.3d at 1090. 
that the replacement of a common law rule with a statutory one, as such, should have no bearing on whether a regulatory taking has occurred. 